\title{
Altos e baixos da crítica literária dialética
}

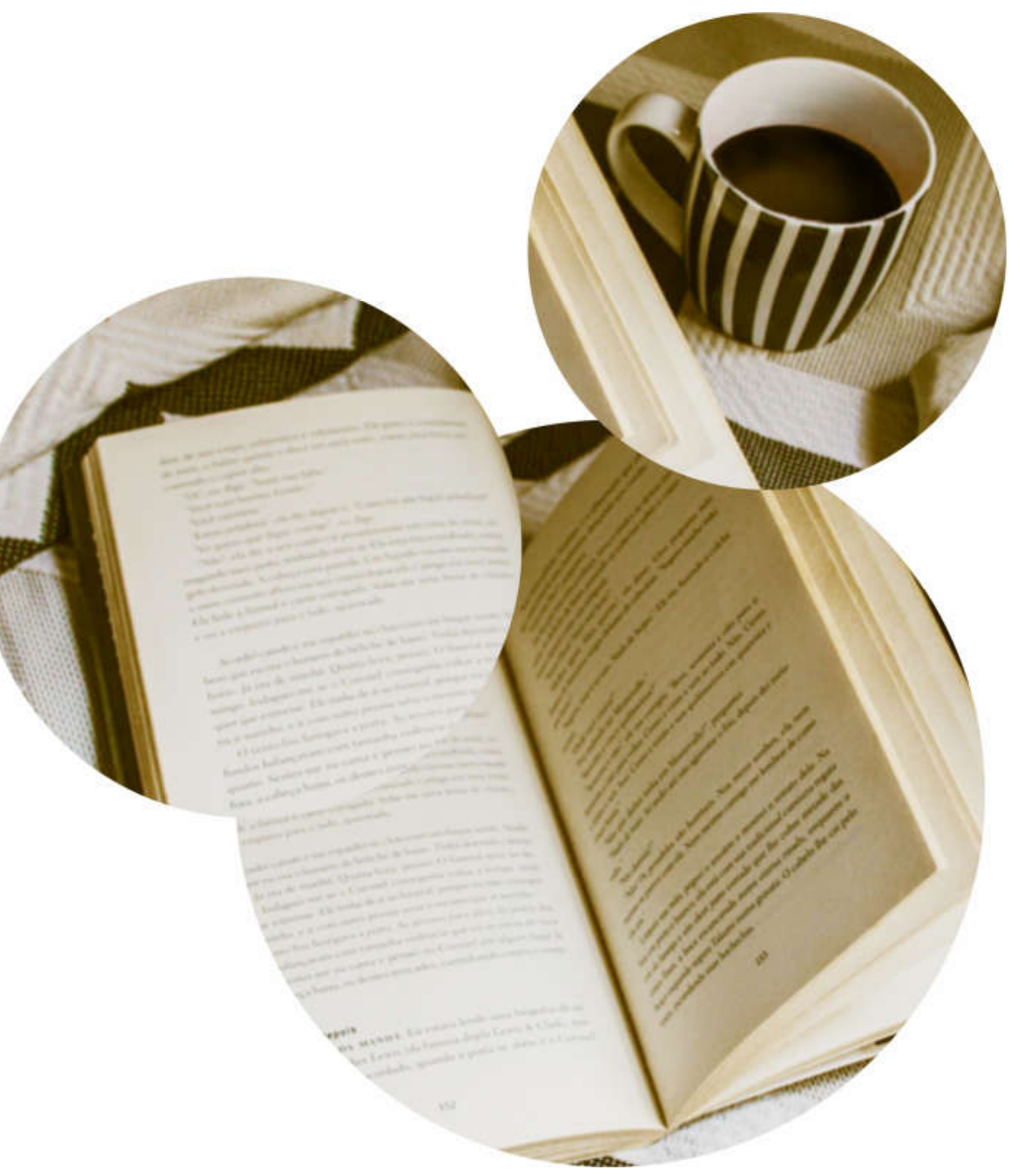

\section{Rogério Cordeiro}

Doutor em Letras pela Universidade Federal do Rio de Janeiro (UFRJ). Professor da Faculdade de Letras da Universidade Federal de Minas Gerais (UFMG), onde atua na graduação e no Programa de Pós-graduação em Estudos Literários. Coorganizador, entre ouros livros, de A crítica literária brasileira em perspectiva. São Paulo: Ateliê, 2013. cordeiro.ufmg@gmail.com.br 


\section{Altos e baixos da crítica literária dialética}

Ups and downs of dialectical criticism

Rogério Cordeiro

\section{RESUMO}

O objetivo deste artigo é sistematizar e divulgar ideias-chave da crítica literária de esquerda, notadamente de extração marxista, chamando atenção para conceitos e modos de reflexão. A questão central recai sobre o problema do método de abordagem histórica da literatura, colocando em resumo e em perspectiva a contribuição de Marx, Engels, Lukács, Bakhtin, Adorno, Benjamin e os nossos Antonio Candido e Roberto Schwarz. Estes autores partiram da condição prévia para elaborarem de maneira particular um ângulo de visão que revelasse a forma de representação artística como uma espécie de depoimento crítico e armado da sociedade correspondente. Por isso a diversidade de tendências analíticas dentro da mesma tradição.

PALAVRAS-CHAVE: marxismo; crítica literária; processo histórico.

\begin{abstract}
The aim of this paper is to sistematize and to publicize milestone ideas of left-wing literary criticism, notably of Marxist lineage, insofar as it pays attention to concepts and pondering modes. The crux of the matter is the issue of historical approach as an analytical method of literature, by summing up and putting into perspective the hallmark contributions of Marx, Engels, Lukács, Bakhtin, Adorno, and Benjamin, as well as our Brazilian thinkers Antonio Candido and Roberto Schwarz. These authors started from the precondition to elaborate in a particular way an angle of vision that would reveal a form of artistic representation as a kind of critical and armed testimony of the corresponding society. It follows then that the diversity of analytic trends within the same tradition.
\end{abstract}

KEYWORDS: marxism; literary criticism; historical process.

Reconhecer as implicações mútuas entre literatura e sociedade é uma das providências mais progressistas da teoria crítica. Do ponto de vista histórico, é uma das conquistas da modernidade, pelo menos em sua dimensão questionadora e combativa. Ao observar seu percurso desde o surgimento, um olhar desprovido de preconceitos reconhece logo que tais implicações se desenvolveram e apuraram, e também diversificaram, gerando um número expressivo de subformações com características marcantes e muito variegadas. Entre as opções à escolha, eu gostaria de chamar atenção para uma tradição específica: a crítica literária dialética. Como outras correntes desse campo, essa teoria crítica literária possui um concerto instrumental sócio-histórico subjacente, cujas linhas de força são interessantes discutir. Não vou empreender discussão conceitual sobre elas, mas expor em linha sumária sua constituição e seu desenvolvimento, atentando para as variações e as mudanças da obra e do pensamento dos principais autores que envigoraram esse campo de análise. 
Eles serão analisados adiante a partir de seu encadeamento conceitual e teórico, mas não é por isso apenas que formam uma tradição e sim, e mais importante, pela conduta intelectual que atravessa e norteia os seus respectivos trabalhos, a saber, incorporaram à massa crítica da literatura as múltiplas determinações sociais de seu próprio tempo como sendo estruturações abrangentes e autotransformadoras. Em outras palavras, esses autores partiram da condição prévia para elaborarem de maneira particular um ângulo de visão que revelasse a forma de representação artística como uma espécie de depoimento crítico e armado da sociedade correspondente. Daí a diversidade de tendências analíticas dentro da mesma tradição. A intuição para o concreto moldou um procedimento intelectual, levou à necessidade de apreensão da lógica histórica contemporânea como premissa de um método de análise e interpelação da literatura. Portanto o método conssiste apreender fatores não metodológicos, método cuja força de penetração resta indicar.

Tentando fazer desta exposição algo mais claro e planejado, optei por situar os autores individualmente, de maneira esquemática e sumária, com informações básicas para se perceber a linha evolutiva.

Vou começar pelo começo: Marx e Engels. Eles nunca escreveram um estudo sistemático sobre literatura, mas era comum que fizessem referências literárias em seus estudos de filosofia, economia ou história. Usavam passagens literárias com muito discernimento como imagens de representação na formulação desses campos, a rigor não literários. Por exemplo, em uma passagem de $O$ capital, quando explica de maneira conceitual a "forma dinheiro", Marx remete à tragédia Antígona, de Sófocles: "Nunca entre os homens floresceu uma invenção assim/ Ela arrasa até cidades/ Afasta os homens/ Impele almas honestas ao aviltamento" ${ }^{1}$ Reparem que o texto está se referindo ao aspecto desagregador do dinheiro em seu contexto original, isto é, na sociedade antiga, mas Marx o desloca para o mundo moderno, identificando a partir dele o caráter do mundo burguês. Assim o coloca em rede num conjunto de ações reais de Estados e empresas: a guerra, a competição, a alienação e a coisificação são componentes de um sistema geral de sociabilidade no qual o dinheiro é o centro de medida. A liberdade dessa ressignificação é fruto da experiência de leitor e ao mesmo tempo da sensibilidade para a experiência histórica contemporânea. O golpe de vista é um método. Mais ainda, o deslocamento faz com que analogias singulares encontradas no detalhe possam fazer compreender a totalidade de um processo. A título de nota, totalidade aqui, na tradição dialética, não representa o todo infinito, extenso e amontoado - o "todo homogêneo e vazio" de que fala Benjamin² -, mas um conjunto estruturado e intensivo, historicamente específico, com sua gênese e desenvolvimento articulados.

\footnotetext{
${ }^{1}$ MARX, Karl. O capital: crítica da economia política: livro I - o processo de produção do capital. 2. ed. São Paulo: Boitempo, 2017, p. 206, n. 92.

${ }^{2}$ BENJAMIN, Walter. Sobre o conceito da História. In: Obras escolhidas I: magia e técnica, arte e política. 3. ed. São Paulo: Brasiliense, 1987, p. 229.
} 
Lembre-se que antes de decidir pela história e pela filosofia, pela política e pela economia, o primeiro grande interesse intelectual de Marx era pela literatura (ele desejava ser poeta), e esse gosto nunca o abandonou, como revela o seu genro, Paul Lafargue:

Marx conhecia Heine e Goethe de cor e costuma citá-los nas conversas. Lia sempre obras de toda a literatura europeia. Relia Ésquilo todos os anos no texto original grego; venerava esse autor e Shakespeare como os maiores gênios dramáticos que a humanidade conhecia. Dante e Burns eram seus poetas prediletos. Era um grande leitor de romances. Tinha preferência pelos do século XVIII particularmente Fielding. Os romancistas modernos que mais o divertiam eram Paul de Kock, Charles Level, Alexandre Dumas pai e Walter Scott. Para ele, acima de todos estavam Cervantes e Balzac. Dizia que Dom Quixote era a epopeia da cavalaria moribunda, cujas virtudes tornavam-se ridículas e malucas no mundo burguês nascente. Sua admiração por Balzac era tão profunda que planejava escrever uma crítica de sua grande obra, A comédia humana. Marx sabia todas as línguas europeias. Quando se dedicou ao estudo da língua russa, em seis meses já dominava o idioma, a ponto de usufruir da leitura dos autores russos que mais estimava: Púchkin, Gógol e Shchedrin. ${ }^{3}$

A citação é longa, porém útil para dar ideia do lugar da literatura no pensamento de Marx. Para completar o quadro, lembre-se ainda que Marx foi aluno de August Schlegel (um dos proeminentes idealizadores da escola romântica de Jena) no curso sobre Homero na Universidade de Bonn. Schlegel descreve Marx como um aluno "dedicado e atento". ${ }^{4}$

Feita essa digressão, gostaria de mostrar o outro lado da equação literatura e história para ele. Como vimos, Marx pontuou suas análises históricas e econômicas com passagens da literatura. Por outro lado, também fez análise literária a partir de uma compreensão histórica rigorosa. Repetindo, nem ele nem Engels escreveram obras de crítica literária, mas eram instados por escritores que pediam com frequência alguma opinião sobre obras em andamento. Um caso exemplar é o da escritora feminista e socialista inglesa Margareth Harkness, que solicitou apontamentos a Engels sobre seu livro. Na carta de Engels se encontra a clássica definição de realismo e de forma objetiva como noções ou conceitos correspondentes que irão marcar a inflexão dessa tradição crítica: “Estou longe de censurá-la por não haver escrito um relato puramente socialista, um 'romance de tendência' - como dizemos nós, os alemães, para sublinhar os conceitos sociais e políticos do autor. Não é a isto que me refiro. Quanto mais dissimulados estejam os pontos de vista do autor, melhor será para a obra artística". ${ }^{5}$

Duas coisas merecem comentário: primeiro, reparem que Engels vai contra a ideia de literatura como ideologia (uma distorção e uma simplificação de que acusam o marxismo em geral); segundo, que para ele as convicções do

\footnotetext{
${ }^{3}$ LAFARGUE, Paul. Recordações pessoais sobre Karl Marx (1890). In: ALBERT, André (org.). Marx pelos marxistas. São Paulo: Boitempo, 2019.

${ }^{4}$ HEINRICH, Michael. Karl Marx e o nascimento da sociedade moderna: biografia e desenvolvimento de sua obra. São Paulo: Boitempo, 2018, p. 151.

${ }^{5}$ ENGELS, Friedrich. Carta a Margareth Harkness - abril de 1888. In: MARX, Karl e ENGELS, Friedrich. Cultura, arte e literatura: textos escolhidos. São Paulo: Expressão Popular, 2012.
} 
escritor não são parâmetros artísticos e podem mesmo desestetizar a literatura. Sua atenção se dirige então para a fatura artística da literatura:

$O$ realismo a que me refiro se manifesta, inclusive, independentemente dos pontos de vista do autor. [...] Um dos traços mais valiosos do velho Balzac, é que ele se viu forçado a escrever contra as suas próprias simpatias de classe e preconceitos politicos, que tenha visto o caráter inevitável da ruína de seus aristocratas prediletos e os tenha descrito como homens que não mereciam sorte melhor e que visse os verdadeiros homens do futuro precisamente onde eles se encontravam. ${ }^{6}$

A forma literária aqui é objetiva porque ela reflete o andamento histórico e não as preferências pessoais do escritor. Seu poder de clarificação reside na capacidade de expor a fatura artística em sua plenitude. $\mathrm{O}$ autor e as condições subjetivas de criação não são riscados do mapa, mas aparecem em situação, ou seja, entram como resultados objetivos por sua vez. As categorias estéticas se historicizam também e o constructo adquire massa crítica em razão da configuração de uma realidade múltipla e multiforme. Vejam, por exemplo, o debate estabelecido por Marx e Engels com Ferdinand Lassalle, um escritor socialista que envia aos renomados líderes comunistas os originais de uma tragédia que estava escrevendo e espera opinião. Lassalle se encontra em exílio na Alemanha, Marx, também exilado, estava em Londres e Engels em Manchester, tocando os negócios da família. Interessa aqui mostrar as observações estéticas que estavam em discussão.

Em uma de suas cartas, Marx pondera sobre as incongruências do método de composição que afetava de maneira peculiar as personagens, as quais não conseguiam reunir na própria personalidade os centros de forças subjetivas necessárias para se constituírem com integralidade e verossimilhança: experiência social, consciência do mundo e reflexão crítica objetiva. Ainda segundo Marx, a partir dessas categorias as personagens adquiririam forma de expressão, enquanto a ausência ou o rebaixamento delas implicaria em perda de energia no campo artístico. Dizendo isso, Marx justifica suas conclusões com um exemplo concreto, referindo-se à maneira de composição de Shakespeare, a quem considerava um realista exemplar: "Deverias ter shakespearizado mais [as personagens], ao passo que ponho na tua conta, como teu equívoco mais significativo, o schillerizar, ou seja, a transformação de indivíduos em meros alto-falantes do espírito da época". ${ }^{7}$

Entendendo a poética desses autores, tem-se uma ideia mais clara a respeito das observações de Marx: Shakespeare construía as personagens de modo que elas encarnassem as determinações históricas, pois as contradições subjetivas, não eram só subjetivas, mas figuração dos conflitos sociais que eram internalizados pelas personagens até sedimentá-las na própria personalidade, enquanto Schiller, por outro lado, não conseguiu o mesmo êxito em seus dramas históricos, com personagens esquemáticas, dotadas de excesso de pensamento, voluntariosas, sem conseguir reunir em si a totalidade da vida e

\footnotetext{
${ }^{6}$ Idem, ibidem, p. 67-69.

${ }^{7}$ Carta de Karl Marx a Ferdinand Lassalle. 19 de abril de 1959. Ver Apêndice: correspondência entre Lassalle, Marx e Engels sobre Sickingen. In: LUKÁCS, György. Marx e Engels como historiadores da literatura. São Paulo: Boitempo, 2014
} 
expressá-la na forma. Vemos que Marx não apenas possuía critérios estéticos bem formados, mas também que meditava sobre eles e os usava com discernimento crítico quando fazia análise literária.

Engels também faz apontamentos usando categorias estéticas a partir de princípios que a historicizavam, isto é, que as faziam traduzir uma concepção de história. É o que transparece num trecho de sua carta para Lassalle, onde comenta sobre a intensidade trágica da peça dizendo que ela se mostra anacrônica, uma vez que os tempos modernos rebaixaram qualquer possibilidade de intensidade vivida e com ela os sentimentos trágicos, tornando-os inexpressivos. Em outras palavras, havia desalinho entre a concepção literária de Lassalle e o universo representado, desalinho que punha à prova a eficácia artística da obra. No fim dessa carta, Engels explica seu método de análise: “O senhor percebe que estou medindo seu opus por um critério muito elevado, o mais elevado possível, tanto em termos estéticos quanto em termos históri$\cos ^{\prime \prime} .{ }^{8}$ Nota-se uma exigência conceitual: o ponto em que o artístico e o social se integralizam como produtor de forma.

Passando agora ao primeiro grande crítico literário dessa tradição, o percurso de György Lukács mostra particularidades definidoras da teoria dialética no contexto das teorias literárias em geral. Seu primeiro grande estudo foi $A$ teoria do romance, no qual se analisa pela primeira vez a forma do gênero em face à sociedade que o produziu, ou seja, da sociedade burguesa. Assim, valores históricos em formação, como razão, individualismo, autoconsciência de existência e de vida social, passam a integrar a estrutura literária, especificando a forma-romance. O livro é publicado em 1914 e logo depois ocorrem eventos históricos que irão mudar a configuração do mundo bem como as convicções estéticas de Lukács. É preciso ver esses fatores relacionados entre si e ainda como uma teoria crítica internaliza as forças sociais de sua época e as metabolizam em conceitos.

Lukács modifica suas convicções e as reformula a partir de sua experiência histórica vivida, marcada pela primeira guerra mundial (1914-1918) e pela revolução russa (1917). Estes eventos revelaram a ele as contradições históricas da sociedade capitalista: a guerra mostrou que a própria lógica de desenvolvimento desse sistema econômico iria levar à autodestruição social e a revolução russa apresentou uma via de superação das contradições criadas por esse sistema e seu subproduto, o imperialismo. Esses acontecimentos levaram Lukács a se aprofundar nos estudos de Marx e Engels e criaram as condições de confrontação teórica com as bases de sua Teoria do romance, livro de concepções idealistas, inspiradas em Hegel, Kant, Simmel e Kierkegaard. Inicia então uma leitura cerrada das obras fundamentais de concepção dialética, como Manuscritos econômico-filosóficos e os Grundrisse, que se encontravam ainda inéditos nos arquivos pessoais de Marx depositados na União Soviética. Como resultado ele começa a publicar nos anos 1930 uma série de artigos nos quais vai apurando o léxico e o método marxistas, incorporando-os à sua pró-

${ }^{8}$ Carta de Friedrich Engels a Ferdinand Lassalle. 18 de maio de 1859. Ver Apêndice, op. cit. 
pria escrita. Pela primeira vez a noção de forma objetiva é usada de maneira sistemática na tradição crítica literária, criando as bases de um método de interpretação que desnaturaliza a relação literatura e sociedade. Lukács se apoia nos pressupostos marxistas segundo os quais a realidade social é algo estruturado e dinâmico, que produz sua própria transformação em razão da composição de forças entre classes sociais, ou seja, a objetividade social é uma forma. A partir disso, elabora que a literatura - enquanto unidade artística organizada - é ela mesma uma forma e que a homologia entre ela e a sociedade se dá nesse nível, no nível da mediação. Por isso a literatura jamais deverá ser entendida como cópia da realidade. Segundo esse ponto de vista, a literatura sedimenta a forma do processo histórico sem que seja uma cópia dela. Para Lukács,

O conteúdo completo da obra de arte há de se converter em forma para que seu verdadeiro conteúdo alcance eficácia artística. A forma é a suprema abstração, a modalidade da condensação do conteúdo e a agudização extrema de suas determinações; é o estabelecimento das proporções justas entre as diversas determinações e o estabelecimento da hierarquia da importância entre as diversas contradições da vida refletidas pela obra de arte. [...] Isto não significa que toda obra de arte deve refletir a totalidade objetiva e extensiva da vida. Ao contrário [...] a totalidade da obra de arte é uma totalidade intensiva: é a coerência completa e unitária daquelas determinações que revestem importância decisiva - objetivamente - para a porção de vida que se plasma. ${ }^{9}$

No decorrer dos anos 1930 Lukács escreve ainda alguns outros ensaios sobre o romance - "O romance" (1934), "Informe sobre o romance" (1935) e "O romance como epopeia burguesa" (1935) -, depurando sua apreensão inicial a respeito da forma sócio-histórica daquele gênero. As conclusões especulativas ou abstratas que aparecem na Teoria do romance são extirpadas aos poucos e com segurança até que o autor sistematiza uma crítica severa com respeito a elas. ${ }^{10}$ Mas antes disso, em 1937, Lukács publica O romance histórico (primeiro em russo e vertido por ele mesmo para o alemão em 1954). É este livro e não o de 1914 que se notabiliza como o seu grande estudo sobre o romance. Aqui ele supera os resíduos metafísicos e apreende a materialidade histórica na forma daquele gênero e a necessidade artística que corresponde a ela, o que leva a uma reviravolta muito representativa no campo dos estudos literários: superar o historicismo vulgar, que só reconhece o social em uma obra literária quando aparece como matéria da ficção, e compreender como o social penetra tão profundamente as estruturas internas da obra, passando a ser seu fator de organização.

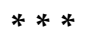

Assim como os autores acima, Mikhail Bakhtin é um caso de deformação da recepção crítica. Sua adoção no ocidente foi muito impactante, mas

\footnotetext{
${ }^{9}$ LUKÁCS, Georg. Arte y verdad objetiva. In: Problemas del realismo. México: Fondo de Cultura Económica, 1966, p. 35 e 36 e 23, respectivamente.

${ }^{10}$ Ver Prefácio de 1962. Idem, A teoria do romance. São Paulo: Duas Cidades/Editora 34, 2000.
} 
enviesada. Primeiro ele foi apropriado pelos estudos do discurso de base idealista que minimizou até fazer desaparecer a concepção materialista que fundamenta os problemas de linguagem; segundo, perdeu-se o significado de sua inserção no contexto cultural e ideológico da Rússia do período entre guerras que condiciona e explica as suas descobertas; por fim, as traduções foram influenciadas pela interpretação pós-estruturalista francesa, acarretando sérias distorções conceituais.

Para comentar o seu principal estudo de literatura, Problemas da poética de Dostoiévski, é bom situá-lo no contexto. Ele foi elaborado dentro do círculo de estudos formado por intelectuais ligados entre si a partir de questões comuns, autores que compunham entre as décadas de 1920 e de 1930 um grupo de estudos que fazia uma interpretação mais livre de Marx, à margem do dogma ideológico do Partido Comunista Soviético. Desse modo, o livro de Bakhtin fica ladeado por O método formal nos estudos literários (1928), de Pavel Medvedev, e Marxismo e filosofia da linguagem (1929), de Valentin Volochinov.

Bakhtin publicou seu estudo em 1929, portanto simultâneo aos demais. Nele se apresenta o conceito de polifonia como um procedimento técnico importante não somente na definição do estilo de Dostoiévski, mas ainda para pensar o romance moderno de maneira geral. Seu uso se mostrou versátil e, com o tempo, inespecífico, mas nem por isso podemos dizer que seu poder de discernimento não perdeu força, porque na origem existia um lastro materialista que foi sendo apagado paulatinamente e no seu lugar ficou a tendência em ver a linguagem como jogo arbitrário de signos, no qual tudo pode se representar por qualquer coisa. $\mathrm{O}$ caráter social desse jogo é fator essencial da crítica literária bakhtiniana, sem o qual se perde seu caráter específico de compreensão mútua de literatura e sociedade. Nas palavras do autor,

De fato, o romance polifônico só pode realizar-se na época capitalista. Além do mais, ele encontrou terreno mais propício justamente na Rússia, onde o capitalismo avançava de maneira quase desastrosa e deixara incólume a diversidade de mundos e grupos sociais que não afrouxaram, como no ocidente, seu isolamento individual no processo de avanço gradual do capitalismo. [...] Criavam-se, com isto, as premissas objetivas da multiplanaridade essencial e da multiplicidade de vozes do romance polifônico. ${ }^{11}$

Vejam que Bakhtin está condicionando a descoberta de uma forma estilizada de narração ao processo histórico objetivo particular de uma sociedade particular. O desenvolvimento imperfeito do capitalismo na Rússia, que Trotsky definiu como um "desenvolvimento desigual e combinado"12, foi captado pela imaginação criadora de Dostoiévsky, que, por sua vez, soube imaginar as virtualidades artístico-formais que essa realidade lhe dispunha. Por isso, Bakhtin definiu Dostoiévski como um "realista no mais alto sentido"13, porque é a realidade social e histórica que aciona os mecanismos de formalização literária desse escritor. Não o realismo espelhista, preso ao factual ou à

\footnotetext{
${ }^{11}$ BAKHTIN, Mikhail. Problemas da poética de Dostoiévski. 2. ed. Rio de Janeiro: Forense Universitária, 1997, p. 19.

12 TROTSKY, Léon. A história da revolução russa, v. 1. 3. ed. Rio de Janeiro: Paz e Terra, 1977, p. 24 e 25.

${ }^{13}$ BAKHTIN, Mikhail, op. cit., p. 60.
} 
imediatez de seu significado, mas um realismo que reelabora o fluxo processual do desenvolvimento histórico, que capta e estiliza as linhas de força invisíveis que estruturam a formação social mundial contemporânea a ele.

Em outras palavras, o que Bakhtin está elaborando aqui é o mesmo sobre o que eu mencionei antes: o dispositivo histórico da obra literária não se define por causa da referenciação aos fatos ocorridos, modos de vida, hábitos, valores, ideias etc., que são representados nela, mas pela capacidade que essa obra tem de internalizar as estruturas que condicionam esses fatores em toda sua complexidade e as depurar artisticamente, metabolizando a realidade social em chave estética.

Retomando essa última ideia, encontramos em Theodor Adorno a condensação conceitual necessária que irá decantar uma postura ao mesmo tempo filosófica e analítica. Em sua obra tardia e inacabada, Teoria estética (1969), ele desenvolve reflexões curtas em grande número sobre a questão da figuração artística da realidade histórica: “Os processos e as funções históricas encontram-se [nas obras] já sedimentados e exprimem-se".${ }^{14}$ Isso aqui é muito importante e talvez passe despercebido: ele diz que a história, enquanto processo, uma vez internalizada, se exprime como tal. A expressão, como se sabe, é um movimento de dentro para fora, um movimento imanente, não induzido, o que quer dizer que a sociedade uma vez transfigurada pela criação artística é ela mesma força de transfiguração, pois penetra as estruturas internas da obra muito profundamente, até que, sem deixar de ser processo social, se constitui como forma artística, como estilo de linguagem. Em outra passagem, coloca a premissa de outro modo, tornando a ideia mais clara: "A forma [artística] é conteúdo [histórico] sedimentado" ${ }^{15} \mathrm{O}$ estilo, portanto, não é forçosamente individual; como vimos a respeito de Dostoiévsky, o estilo é uma formalização do processo social. Adorno realça, como Lukács antes dele, a linhagem hegeliana que sobreviveu no marxismo, segundo a qual o estilo é manifestação abstrata de um elã histórico em sentido estrito.

Essa formulação orientou muitos dos seus estudos sobre literatura. No ensaio sobre Balzac, por exemplo, Adorno reconhece a energia estruturadora não evidente que atravessa a arte e a vida social: "Balzac está livre da ilusão burguesa de que o indivíduo é essencialmente para si. Seus romances não representam somente a supremacia dos interesses sociais, especialmente econômicos, sobre a psicologia privada, mas também as gêneses sociais dessa psicologia". ${ }^{16}$

Reparem no alcance desse tipo de análise: ela identifica um problema artístico (a composição do caráter da personagem, sua essência humana, sua psicologia - para usar um termo moderno, que não era corrente no tempo de Balzac) e procura ver através dele (o problema artístico) a estrutura da sociedade correspondente. Esse método põe em prática a teoria que estamos discu-

\footnotetext{
${ }^{14}$ ADORNO, Theodor W. Teoria estética. Lisboa: Editora 70, 1970, p. 131.

${ }^{15}$ Idem, ibidem, p. 16.

${ }_{16}$ Idem, Reading Balzac. In: Notes to literature, v. 1. New York: Columbia University Press, 1993, p. 126.
} 
tindo, pois parte do princípio de que a estrutura da sociedade foi incorporada ao conteúdo do romance e se sedimentou, tornando-se um princípio artístico de organização.

E o que dizer de sua análise de Fim de partida de Samuel Beckett? Para Adorno é uma peça dramatúrgica que prima por rarefazer ao extremo a materialidade da vida, que cria um cenário pós-tudo, personagens pós-humanas, linguagem pós-representativa. Existencialismo francês, fenomenologia alemã, anti-historicismo e estética do absurdo se juntam para moldar uma forma tão abstrata que parece desaparecer. No entanto, ele gira a plataforma de análise e vê o contrário: o que parecia perda de sentido se mostra o sentido do mundo social contemporâneo, isto é, um mundo sob a hegemonia do capitalismo e suas anomalias: "Não se suprime o temporal da existência, a qual contudo só seria tal temporalmente, pois extrai dela o que o tempo - a tendência histórica - está a ponto de carregar. [...] Da história meramente aparece seu resultado como sedimento". ${ }^{17}$

Vemos aqui uma leitura alinhada com os pressupostos metodológicos que estamos discutindo, acrescida de uma reflexão mais abstratizante, digamos assim, mas sem perder de vista - aliás, enfatizando - a conformação estética da realidade em um nível artístico que por princípio parece negar essa mesma conformação.

\section{$* * *$}

Trocando em miúdos e observando as peculiaridades de cada um, esse é o procedimento de análise de Walter Benjamin. Para usar de brevidade e tentar uma explicação sistematizada, vou me ater a um problema que atravessa a produção intelectual de Benjamin e mostra, nesse desenvolvimento, seu percurso de aquisição e amadurecimento da verve dialética. Trata-se do problema da modernidade, o qual mudou de forma e perspectiva ao longo dos anos. Também aqui é notável a inflexão do momento histórico sobre a formação intelectual do crítico e sua concepção teórico-crítica: ascensão do nazismo, totalitarismo oligopólico do capital e massificação ideológica levaram Benjamin a uma postura radical de contestação dos rumos do desenvolvimento histórico.

Voltando à questão da modernidade, tomem a evolução do ponto de vista em três estudos desse autor. O primeiro trabalho no qual desenvolve uma discussão sobre esse conceito é sua tese de doutorado, O conceito de crítica de arte no romantismo alemão, de 1919. Aqui, a noção de modernidade é abstrata, estritamente formal, referindo-se a um método de reflexão a partir do idealismo alemão e depois incorporado pela primeira geração do romantismo, que o converteu numa concepção de arte. Benjamin insiste, por exemplo, no ato do pensar infinito, isto é, "o pensar que pensa o pensamento que se pensa", um método de circunvolução reflexiva desenvolvido por Kant e Fichte. ${ }^{18} \mathrm{~A}$ modernidade é assim associada a uma postura ruminativa do pensamento, restrita ao mundo intelectual, à reflexão pura, sendo, portanto, desistoricizada. A

${ }^{17}$ Idem, Trying to understand endgame. In: Notes to literature, op. cit., p. 246 e 247.

${ }^{18}$ Cf. BENJAMIN, Walter. O conceito de crítica de arte no romantismo alemão. São Paulo: Iluminuras, 1993. 
dialética específica neste caso corre no vazio, na especulação puramente linguageira e conceitual, destracionada dos condicionamentos sociais que a determinam no interior de um processo específico. Essa é a postura que Benjamin procura superar no seu próximo trabalho de fôlego, Origem do drama trágico alemão, tese de livre-docência de 1925. Aqui a história é incorporada à reflexão e à forma artística, enquanto obra acabada. Benjamin nota, por exemplo, que a linguagem barroca com seu jogo estilístico dos contrários seria a forma sedimentada das forças sociais que atuam no seu contexto histórico, marcado pelo declínio dos universais abstratos, e que a melancolia dominante do estado de espírito trágico-barroco seria resultado da vacuidade de projetos concretos em meio de uma guerra religiosa que estava em curso. A história está presente enquanto pressuposto efetivo do momento artístico, mas ela não aparece como força motriz essencial desse processo, isto é, não aparece como transfiguração da luta de classes.

Foi nessa época que Benjamin começou a se dedicar de fato ao marxismo: primeiro pelo aspecto político e depois o teórico. Nos anos 1930 ele escreve uma série de artigos a respeito dos efeitos do desenvolvimento capitalista sobre a cultura, e dedica-se especialmente à obra de Baudelaire. Na coletânea Charles Baudelaire: um lírico no auge do capitalismo, Benjamin utiliza pela primeira vez uma noção materialista para tratar do problema da modernidade, e faz isso com base em Marx e no próprio Baudelaire. Sua intuição o leva por caminhos surpreendentes, desentranhando significado social naquilo que parecia escapar a ele. Por exemplo, a transmutação do desejo de revolta presente em As flores do mal, algo que para o crítico transcende a biografia do poeta e alcança representar o mundo em convulsão. No entanto, a correlação dessa disposição com as convicções políticas de Baudelaire (que participou das lutas de 1848 em Paris com armas na mão) ficam em segundo plano e Benjamin se volta para figurações mais indiretas. Esse trabalho com os extremos da figuração é golpe de vista dialético.

Vejam um exemplo. A prostituta, personagem que adquire certo protagonismo no livro, foi explicada de diferentes maneiras: numa leitura sexista, ela foi interpretada como representação da liberdade, dispondo do próprio corpo ao arrepio dos padrões morais vigentes; numa leitura simbólica, é a representação do Diabo, com quem divide o papel da rebeldia; e, numa leitura imanente, representa o alter ego do poeta. Tudo isso aparece na interpretação de Benjamin, mas ele ajusta o foco histórico e acaba se opondo às demais interpretações. Para ele, a prostituta representa o aviltamento do ser humano histórico (não a mulher em particular, e menos ainda o mito ou o poeta, embora estes sejam também levados de roldão), ou seja, o sujeito fruto de uma dada realidade histórica particular, inscrito no momento do "auge do capitalismo", como diz o título do livro. Em outros termos, a prostituta representa o sujeito social, cultural e economicamente assujeitado, isto é, processado como coisa, como objeto.

Vale aqui uma digressão. Como se sabe, Marx se refere a esse fenômeno como algo próprio do sistema capitalista, a que se deu o nome de reificação. É um fenômeno produzido pela economia mercantil, na qual o sujeito perde valor humano e adquire valor de uso e de troca. Nas palavras de Marx, 
“a produção [capitalista] produz não somente um objeto para o sujeito, mas também um sujeito para o objeto". ${ }^{19}$ Para Baudelaire, que compartilhava inúmeras e surpreendentes analogias com Marx, o assujeitamento às forças de pressão assume diferentes formas, mostrando se tratar de um sistema completo de vida. Voltando ao Benjamin e à questão da prostituição, ele coloca o problema tal como aparece no poeta francês, isto é, no centro das transformações capitalistas: "Se a mercadoria tivesse uma alma - com a qual Marx ocasionalmente faz graça - esta seria a mais plena de empatia já encontrada no reino das almas pois deveria procurar em cada um o seu comprador. [...] E a 'santa prostituição da alma' não pode ser outra coisa que a prostituição da alma da mercadoria". ${ }^{20}$

Vou torcer um pouco o debate e dar um salto largo para me referir à situação brasileira. Para isso vou comentar a projeção crítica de Antonio Candido e Roberto Schwarz, mas antes gostaria de chamar atenção para algo que eu acho fundamental para compreender corretamente a ligação deles com a tradição marxista: eles não são "teóricos do marxismo", como é comum identificar um marxista no Brasil, ou seja, eles não analisam os conceitos, os princípios ou o método marxista. O que eles fazem é o uso específico do marxismo, uma vez que as matérias de reflexão deles (literatura e sociedade) são específicas, pertencentes a outra latitude do sistema já globalizado. No que se refere à questão do método (que aqui interessa em particular), essa diferenciação é um pressuposto do próprio marxismo, uma vez que o vínculo entre os fenômenos particulares e o movimento geral que os determina deve ser observado e trazido à reflexão como condição prévia. Assim, ao tratar de uma formação histórica específica (no caso, a brasileira), o crítico dialético precisa configurá-la em teoria, caso contrário a teoria irá falsificar a análise que se propõe.

Antonio Candido entrou em contato com o marxismo quando ainda era adolescente, mas, como ele mesmo disse, "não calou muito fundo". Mais tarde, quando cursava sociologia na Universidade de São Paulo e com estímulo do professor Jean Maugüê, faz um estudo mais detido sobre o Livro I de $O$ Capital. A partir daí, a construção de uma chave de interpretação do Brasil (especialmente sua literatura) e a militância política no campo da esquerda realimentaram o papel da dialética no pensamento e na vida dele. A recepção da dialética marxista por ele é inequívoca, mas não é óbvia. Vou citar duas declarações que mostram uma recepção ao mesmo tempo enfática e seletiva. Na primeira ocasião, ele afirma: "O materialismo dialético me revelou a importância das obras de juventude de Marx, como A ideologia alemã, que li e foi

\footnotetext{
${ }^{19}$ MARX, Karl. Grundrisse: Manuscritos econômicos de 1857-1858/Esboços da crítica da economia política. São Paulo: Boitempo, 2011, p. 47.

${ }^{20}$ BENJAMIN, Walter. Charles Baudelaire: um lírico no auge do capitalismo. São Paulo: Brasiliense, 1989, p. 53.
} 
o texto marxista do qual recebi maior influência". ${ }^{21}$ Logo mais, ajusta o foco sobre essa filiação: "Portanto, repito: sofri a influência do marxismo e basta ler o que escrevo para ver isso; mas nunca fui marxista propriamente dito e nunca quis me dizer marxista, para guardar essa liberdade, sobretudo no campo da arte" ${ }^{22}$

Vemos ainda que ele mantém uma atitude modalizadora no referente à teoria literária. Quando se refere a Lukács, por exemplo, manifesta uma opinião aparentemente contraditória. Numa entrevista a um grupo de professores interessados em suas fontes teóricas, afirma: "Nunca adotei a crítica marxista, acho a crítica do Lukács, como crítica, lamentável". Pouco adiante ele refaz a fórmula: "Minha ambição foi sempre fazer uma certa coisa e depois eu a vi bem formulada no Lukács". ${ }^{23}$ Penso que estas declarações, a despeito da dupla fidelidade que pode sugerir, se devem ao modo como o marxismo e a crítica dialética junto se aclimataram no Brasil nos anos 1940 e 1950: muita política e pouca reflexão teórica, o que acabava rebaixando a própria política até o ponto de ela se confundir com voluntarismo, sem atenção para as especificidades da luta de classes no país.

Comentando os estudos de Antonio Candido, é preciso fazer a ressalva de que neles o crítico não comenta muito sua base teórica, não abre polêmica com ela. No seu caso, o mais comum é desenvolver análise literária propriamente dita, estudar as obras pelo que elas apresentam. Também nisso aparece o método objetivo, que ele chamou de "paixão pelo concreto", e complementa: "Na literatura, o texto, na sociologia, os fatos sociais". ${ }^{24}$ Uma das poucas vezes em que anuncia o seu método se encontra no "Prefácio" de O discurso e a cidade, onde declara: “O meu propósito é fazer uma crítica integradora, capaz de mostrar (e não apenas enunciar teoricamente) de que maneira a narrativa se constitui a partir de materiais não literários, manipulados a fim de se tornarem aspectos de uma organização estética regida pelas suas próprias leis". ${ }^{25}$ Notem que se trata daquela formulação que vimos em citações anteriores: as linhas de força que atuam no plano da realidade histórica são internalizadas e adquirem uma lógica própria (não diferente, mas própria), que é estética. Nas palavras do próprio Candido, agora citado no ensaio de 1961, “Crítica e sociologia": "O externo (no caso, o social) importa, não como causa, nem como significado, mas como elemento que desempenha um certo papel na constituição da estrutura, tornando-se, portanto, interno". ${ }^{26}$ Em outras palavras, ele está reiterando a máxima de Adorno segundo a qual "a forma artística é conteúdo social sedimentado". Essa referência possui implicações mais propositadas do que pode parecer à primeira vista, como fica registrado no ensaio "A passagem do dois ao três", primeira versão de "De cortiço a cortiço", quando afirma

${ }^{21}$ CANDIDO, Antonio. A militância por dever de consciência. Teoria \& Debate, n. 2, São Paulo, mar. 1988, p. 4.

${ }^{22}$ Idem, Marxismo e militância: Entrevista. Praga: Revista de Estudos Marxistas, n. 1, São Paulo, 1996, p. 9.

${ }^{23}$ Idem, Entrevista com Antonio Candido. Investigações: Linguística e Teoria Literária, v. 7, Recife, 1997, p. 21.

${ }^{24}$ Idem, Entrevista em 6 jun. 1996. In: JACKSON, Luiz Carlos. A tradição esquecida: os parceiros do Rio Bonito e a sociologia de Antonio Candido. Belo Horizonte: Editora UFMG, 2002, p. 126.

${ }^{25}$ Idem, Prefácio. In: O discurso e a cidade. São Paulo: Duas Cidades, 1993, p. 9.

${ }^{26}$ Idem, Crítica e sociologia (tentativa de esclarecimento). In: Literatura e sociedade: estudos de teoria e história literária. 7. ed. São Paulo: Nacional, 1985, p. 4. 
que Adorno possuía uma "concepção da forma como verdadeira manifestação do social na obra". ${ }^{27}$

Antonio Candido se encaixa no perfil do intelectual eclético, mas conseguiu, pela via do método dialético, integrar áreas bem diferentes entre si, como a estilística, a filologia, a história, a sociologia, a filosofia, a estética etc., manipuladas com exigente juízo de gosto. Ele teve a capacidade de realizar a síntese ajustada das diferentes linhas de força da obra literária, um resultado de sua paixão pelo concreto do texto. Em sua análise de L'assommoir, por exemplo, romance contundente de Emile Zola sobre o aviltamento imposto à humanidade decorrente da proletarização e da precariedade de vida no moderno ambiente urbano, ele vai do retórico-estilístico à sociologia das classes:

Incorporando o ritmo, a sintaxe e o vocabulário do povo para chegar a uma linguagem inovadora, Zola aumenta a taxa de gíria, acentua no discurso indireto a energia coloquial. [...] No capítulo XII vemos Gervaise sozinha no aposento vazio e imundo onde resta um monte de palha que foi do colchão. Deitada nele, sem comer havia um dia e meio, espera em vão que o marido traga algum dinheiro. Num longo trecho, onde personagem e narrador se fundem na subjetividade objetiva do indireto livre, vemos uma espécie de monólogo interior de Gervaise, num tom que discrepa do que era o seu, pois ela cuidava relativamente da fala, como um elemento a mais do esforço de respeitabilidade. Agora, é a gíria agressiva do bairro, que se tornara o dialeto único do marido e acabou por contágio pegando na mulher com o vício da bebida..$^{28}$

Vejam como ele identificou no estilo a configuração da sociedade francesa em combustão, com as lutas sociais determinando a vida íntima das pessoas, redesenhando o perfil psicológico delas. É um golpe de vista bastante desenvolto: partir do social para chegar à subjetividade analisando o estilo, uma mostra do que pode a crítica dialética em sua melhor forma. O quesito propriamente de linguagem estabelece o sistema de mediações entre o concreto e o figurado, pondo em prática aquelas questões de método que eu apontei no início.

Por fim, para falar um pouco mais sobre esse autor, vale a pena discutir sua obra máxima que é a Formação da literatura brasileira. Em nenhum outro livro de fôlego sobre história da literatura a matéria é apresentada com tamanho rigor dialético: cada autor - poeta, romancista, publicista ou historiador da literatura - é analisado a partir do conhecimento profundo da obra deles, estabelecendo conexões pouco evidentes, comparando semelhanças e diferenças de modo que possam formar uma rede integrada de significados, e, desse modo, colocados em perspectiva, vai-se desenhando a substância da evolução ocorrendo simultaneamente no campo social, ideológico, cultural e estético, revelando a tessitura das multideterminações de um processo em curso, processo concreto. É desse modo que um recurso estilístico, um tema ou uma concepção de arte são analisados como repasses transformados de um autor para outro numa sequência contraditória e complementar que vai se estabelecendo objetivamente.

${ }^{27} \mathrm{Idem}$, Duas vezes "A passagem do dois ao três". In: Textos de intervenção. São Paulo: Duas Cidades/Editora 34, 2002, p. 54.

${ }^{28}$ Idem, ibidem, p. 91 e 92. 
O campo de visão é abrangente e não se restringe aos autores brasileiros, abrindo uma perspectiva internacionalista compatível com a mundialização a que o país, na condição de ex-colônia, estava sujeito, sempre, no entanto, privilegiando a formalização no âmbito da forma estética. Alguns exemplos: a cisão espiritual do poeta italiano Metastasio, depois de identificada e avaliada, é analisada como sendo aproveitada por Claudio Manuel da Costa, que atribuiu outro sentido a ela, que, por sua vez, foi por assim dizer abrasileirada, mas ainda vinculada à tradição ocidental, a partir do que reaparece em Fagundes Varela, poeta romântico que antagonizava com o classicismo de Metastasio e Claudio. Essa postura desenvolve para uma figuração subjetiva, realimentada também em parâmetros universais, como nos românticos franceses e alemães, e depois passam nova transformação e tornando-se matéria de reflexão e ironia em Álvares de Azevedo, além de outros poetas e romancistas do período, até serem aproveitadas por Machado de Assis que integrou tudo numa fatura de análise e efabulação de alto nível. Outro exemplo significativo é o da natureza enquanto imagem: aparece primeiro nos árcades italianos e portugueses, muito convencional, depois é ressignificada pelos mineiros e depois transformada pelos românticos (via idealização francesa), seja na poesia de Gonçalves Dias ou no romance de José de Alencar.

Dizendo de outra maneira, Antonio Candido conseguiu descobrir e racionalizar uma disciplina dialética efetiva a partir da configuração formal das obras literárias, colocando a literatura brasileira e a europeia em perspectiva histórica de um só golpe, sabendo especificá-las. Desse modo, analisa a tradição portuguesa, espanhola, francesa, italiana, alemã e inglesa em ritmos de aproximação e diferenciação com relação à nossa. Ora, essa visão global da literatura articulada em função da forma que ela adquire no Brasil - incomum em outros trabalhos do gênero - é resultado de uma determinada força de estruturação. Sem querer forçar a nota, desconsiderar essa particularidade pode ser efeito da falta de costume com as leis dinâmicas da análise dialética, com as quais o crítico lida de maneira bastante consciente e independente. Aos seus críticos, que não são poucos, parece faltar essa mesma consciência e independência - parece que no campo dos estudos literários, mais do que nos historiográficos, a refração aos poderes de clarificação da dialética é bem mais forte, talvez devido à sobreposição de diferentes gerações de teorias de base idealista.

Falando agora de Roberto Schwarz, a teoria marxista nele é bem incorporada e bem resolvida - não é à toa que o historiador Perry Anderson o definiu como "o melhor crítico dialético em qualquer lugar do mundo". ${ }^{29} \mathrm{No}$ "Prefácio" ao seu livro Um mestre na periferia do capitalismo ele assume a filiação: "Meu trabalho seria impensável sem a tradição - contraditória - de Lukács, Benjamin, Brecht e Adorno e sem a inspiração de Marx". ${ }^{30}$ Antes de

\footnotetext{
${ }^{29}$ ANDERSON, Perry. Lula's Brazil. In: London Review of Books, v. 33, n. 7, London, 2001.

${ }^{30}$ SCHWARZ, Roberto. Um mestre na periferia do capitalismo: Machado de Assis. 4. ed. São Paulo: Duas Cidades/Editora 34, 2000, p. 13.
} 
falar sobre a especificidade de seu método de análise e teoria crítica, vale a pena fazer algum comentário sobre seu percurso intelectual.

No fim dos anos 1950, quando ainda era graduando do curso de Ciências Sociais, Schwarz participou de um grupo de estudos sobre $O$ capital. $\mathrm{O}$ grupo contava com alguns alunos e uma maioria de professores pertencentes a diferentes áreas, como filosofia, sociologia, história e economia, cada um contribuindo para o debate à sua maneira. É importante retomar o sentido das conquistas teóricas desse grupo, aproveitando da visão do próprio crítico:

A ideia básica era estudar as peculiaridades sociais, políticas e econômicas do Brasil em especial formas de exploração e dominação - e colocá-las, como mediadoras, no contexto do capitalismo mundial. Isso não era corrente entre nós. De modo geral, os estudos sobre as peculiaridades brasileiras eram voltados para o Brasil, e os estudos do mundo contemporâneo eram voltados para o mundo contemporâneo. O seminário [de Marx] desenvolveu a ideia de que é preciso articular a estrutura de classes interna com o movimento geral da atualidade e enxergar nessa articulação um problema, seja histórico, seja político, seja teórico. ${ }^{31}$

Abrindo parênteses, se vocês repararam, o que ele expõe aqui tem a ver com o que eu acabo de falar sobre Formação da literatura brasileira, e, de fato, eles estavam fazendo mais ou menos a mesma coisa ao mesmo tempo, final da década de 1950. Estamos sob o governo JK, particularmente significativo no processo de modernização no Brasil, que colocou a obrigação de se repensar o processo brasileiro diante dessa etapa do capitalismo mundial. Nesse contexto, a dialética se mostrou uma ferramenta essencial, mas era preciso realinhá-la com a realidade brasileira àquela altura da história. Isso quer dizer que o salto teórico a que estou me referindo possui também um teor objetivo. Ele é produto do processo histórico, pois foram as transformações pelas quais passou o país que levaram às conquistas teóricas de Antonio Candido e do grupo de seminário, incluindo aí Roberto Schwarz.

Voltando à questão do método crítico, alguns exemplos colhidos aqui e ali serão suficientes para mostrar a inflexão que o autor realiza. Na polêmica apreciação sobre a autobiografia de Caetano Veloso - que Schwarz se dispôs a ler como romance, procurando o equilíbrio do narrador -, comenta nos seguintes termos quando o compositor diz haver contribuição exitosa da parte do capitalismo: "É como se por um momento o progresso e a internacionalização se fizessem para o bem de todos e não às custas dos fracos e atrasados". ${ }^{32}$ Reparem que a leitura faz interpretação enviesada, mostrando que por trás da modernidade subsiste uma força regressiva. $\mathrm{O}$ fato de que o biografado não se dê por ela fica em segundo plano, o interessante é ver como um discurso de contestação acaba justificando o inaceitável. Em outra ocasião, na análise da poesia ultramodernista de Oswald de Andrade (minimalista, fragmentada, alegórica e montada), reconhece a disposição de um dado estrutural da realidade histórica: “A modernidade no caso não consiste em romper com o pas-

\footnotetext{
${ }^{31}$ Idem, Entrevista. In: MONTEIRO, Paula e MOURA, Flávio (orgs.). Retrato de grupo: 40 anos do Cebrap. São Paulo: Cosac Naify, 2009, p. 232.

32 Idem, Verdade tropical: um percurso de nosso tempo. In: Martinha versus Lucrécia: ensaios e entrevistas. São Paulo: Companhia das Letras, 2012, p. 75.
} 
sado ou dissolvê-lo, mas em depurar os seus elementos e arranjá-los dentro de uma visão atualizada e, naturalmente, inventiva, como que dizendo, do alto onde se encontra: tudo isso é meu país" ${ }^{33}$

Diferente de Antonio Candido, Roberto Schwarz faz análise da análise, com interesse em elucidar os meandros da teoria crítica por trás da interpretação, e comenta demoradamente a questão do método. Não o faz, porém, de maneira pura, mas, dialeticamente, circunstanciado pela história social, medindo, portanto, o modo como a crítica dialética se instalou e se modificou no Brasil. Assim procede na análise de "Dialética da malandragem", estudo seminal de Antonio Candido sobre as Memórias de um sargento de milícias: "A junção de romance e sociedade se faz através da forma. Esta é entendida como princípio mediador que organiza em profundidade os dados da ficção e do real, sendo parte dos dois planos. [...] Noutras palavras, antes de intuída pelo romancista, a forma que o crítico estuda foi produzida pelo processo social, mesmo que ninguém saiba dela". ${ }^{34}$

Vale a pena destacar este final: a matéria objetiva da literatura não foi o escritor quem criou e podemos mesmo dizer que, ao contrário, o escritor é que é uma criação dela. É uma concepção antiabstrata e antiarbitrária do processo de criação e que se encontra enraizada na tradição crítica marxista: ela foi defendida por todos os autores que eu comentei aqui.

Quanto aos estudos machadianos, vou me referir a um deles, talvez o mais modesto, pelo menos no tamanho, que é "A poesia envenenada de Dom Casmurro". ${ }^{35} \mathrm{O}$ ensaio parte das leituras mais adiantadas sobre o romance, mas as supera (dialeticamente falando), na busca de relações com a formação social brasileira: de um lado, o estudo de Helen Caldwell (O Otelo brasileiro de Machado de Assis, 1960), que desloca a atenção do eixo problematizador do livro, não mais em Capitu, mas no narrador, que manipula a sequência narrativa, reinterpreta os fatos e esconde intenções inconfessáveis por traz de uma prosa persuasiva; de outro, o trabalho de Silviano Santiago ("Retórica da verossimilhança", em Uma literatura nos trópicos 1978), que desconstrói a lógica de argumentação bem armada pelo advogado Bentinho e a volta contra ele. Pois bem, levando essas interpretações em conta, Schwarz vai para outro lado e pega um problema quente (ainda atual) que foi negligenciado (e ainda é): o ponto de vista de um membro da classe dominante colocado em um pedestal de autoridade insuspeita que nem os contemporâneos de Machado nem os críticos posteriores identificaram, como se simplesmente a opinião dos ricos não tivesse contestação à altura. Assim, amor, ciúme, linguagem, cristianismo, saudades, memória etc. são vistos como parte da luta de classes e não a despeito delas. Sem querer "puxar sardinha", esse golpe de vista é fina intuição dialética, que o crítico marxista tem a prerrogativa de ver melhor.

\footnotetext{
${ }_{33}^{3}$ Idem, A carroça, o bonde e o poeta futurista. In: Que horas são? São Paulo: Companhia das Letras, 1989, p. 22.

${ }^{34}$ Idem, Pressupostos, salvo engano, de “Dialética da malandragem". In: Que horas são?, op. cit., p. 141.

35 Idem, Duas meninas. São Paulo: Companhia das Letras, 1997.
} 
Diante de um quadro tão heterogêneo, reunindo autores tão diferentes entre si, fica difícil estabelecer uma síntese segura. Por isso, as conclusões possíveis assumem caráter provisório e sujeito a correções e ajustes, pois cada um desses críticos apresentam uma independência não-comum com relação aos demais - individualmente apresentam grande capacidade intelectual para armar em teoria um compósito de fatores irredutíveis que, uma vez integralizados, clarificam-se reciprocamente.

Lukács alertou para o dado de que, em matéria de teoria crítica, juntar diferentes áreas de conhecimento não é garantia de teses coesas e penetrantes. ${ }^{36} \mathrm{O}$ "ecletismo" pode servir de diversionismo interno se não for pautado por um incoercível senso de proporção ou se se sobrepor à própria disciplina de seu objeto. Pensando em estudos de literatura, convenhamos que o objeto é dos mais fluidos e multiformes, e que a tal disciplina pode se manifestar de diferentes maneiras. Daí que cada um dos autores aqui apresentados e discutidos apresenta um modo completamente particular de análise, cada um engendrou um sistema teórico para si a partir de sua prática de interpretação, através do qual, entretanto, podemos identificar um estilo de pensamento em linha de evolução. De Marx até Schwarz, passando pelos demais (sem esquecer que a transmissão não se esgota no resumo que fiz aqui), a teoria dialética aprimorou as armas de análise para o momento contemporâneo, acrescidas do nada desprezível reconhecimento da especificidade da situação brasileira, que da periferia onde está se modernizou também, embora diferentemente do resto do mundo desenvolvido do grande sistema econômico e cultural globalizado.

Não obstante a individualidade, eles apresentam distintos pontos de confluência que podem ser mais ou menos provocados segundo a circunstância. Para começar, esses autores leram uns aos outros (observando, é claro, as leis de Cronos), e não raro confrontaram opiniões. Não é um clube de pensamento único e homogêneo, mas um núcleo de reflexão que se realimenta a partir da depuração conceitual. Segundo que combinando diferentes campos do conhecimento e da vida (história, psicologia, sociologia, economia, filosofia, estética etc.) e diferentes práticas de análise (leitura cerrada, estilística, comparatismo, teoria narrativa, poética e outras) com intensidades desiguais e combinadas, cultivaram como característica essencial o chamado primado do estético. Terceiro que mantém como lastro da análise e mesmo como postura intelectual o interesse contínuo e sempre alimentado pelo concreto social e suas múltiplas determinações.

Sendo assim, a teoria crítica dialética da literatura não é uma teoria crítica entre outras, dotada de recursos para elucidar um sentido entre tantos que a obra literária pode formalizar. Até onde eu possa enxergar - e é sempre possível objetar questões dessa ordem, o que seria bom para testar as suas possibilidades -, essa teoria possui suficiente elasticidade conceitual para incorporar as demais tendências teóricas sem deturpá-las, mas usando-as para um determinado fim. Não quero dizer com isso que a teoria crítica dialética pode compor com outras sem prejuízo para ninguém; ela pode, mas não é essa a

${ }^{36}$ Cf. LUKÁCS, György. Marx e o problema da decadência ideológica. In: Marx e Engels como historiadores da literatura, op. cit. 
questão, porque poderíamos justificar isso relativizando tudo e dizer que qualquer teoria crítica possui resiliência bastante para cumprir esse papel. Por outros caminhos seria uma nova forma de ecletismo. A questão aqui é: a teoria dialética especifica o seu objeto (a obra literária) e os métodos de análise (outras teorias críticas) historicizando ambos, isto é, colocando tudo sob a perspectiva reveladora das relações sociais que, noves fora, sempre constituem a base das obras como também das teorias, porque também essas são históricas por sua vez. Seria um modo de interpor senso de historicidade a qualquer postura abstratizante, mostrando que aquilo que se vê como autônomo não tem autonomia. Essa não é uma fórmula geral que diz respeito à história como um todo e que poderia planificar e igualar erroneamente os diferentes estilos e procedimentos artísticos (pensando na literatura) bem como os conceitos e métodos (pensando nas teorias críticas). Mas não é o caso, pelo contrário: historicizar significa especificar momentos, individualizar as forças sociais, em outros termos é ver o complexo de maneira complexa.

Artigo recebido em 15 de dezembro de 2020. Aprovado em 25 de janeiro de 2021. 